\title{
Research of Salmonella spp. and evaluation of pathogenicity, cytotoxicity of Escherichia coli isolates proceeding from sparrows (Passer domesticus) $^{1}$
}

\author{
Sineide M.O. Vilela², José W. Pinheiro Júnior ${ }^{3}$, José S.A. Silva² ${ }^{2}$ Fernanda de Pace ${ }^{4}$, \\ Wanderley D. Silveira ${ }^{4}$,Tomoe N. Saukas ${ }^{5}$, Eliane M.F. Reis ${ }^{6}$ and Rinaldo A. Mota ${ }^{5 *}$
}

\begin{abstract}
Vilela S.M.O., Pinheiro Júnior J.W., Silva J.S.A., Pace F., Silveira W.D., Saukas T.N., Reis E.M.F. \& Mota R.A. 2012. Research of Salmonella spp. and evaluation of pathogenicity, cytotoxicity of Escherichia coli isolates proceeding from sparrows (Passer domesticus). Pesquisa Veterinária Brasileira 32(9):931-935. Departamento de Medicina Veterinária, Universidade Federal Rural de Pernambuco, Rua Dom Manuel de Medeiros s/n, Recife, PE 52171-900, Brazil. E-mail: rinaldo.mota@hotmail.com

The aim of this study was to research the occurrence of Salmonella spp. and Escherichia coli in feces samples of sparrows, as well as to identify the pathogenicity, cytotoxicity and sensitivity profile of the isolates to antimicrobial use. Two hundred and twenty eight sparrows were captured in eight farms. The in vitro pathogenicity test was performed by the isolates culture on congo red-magnesium oxalate Agar, whilst the in vivo pathogenicity test was performed in one day-old chicks. In order to study the cytotoxic effects of indicators, samples were inoculated into Vero cells. The results obtained for Escherichia coli isolation confirmed the presence of this microorganism in $30(13.2 \%)$ of the evaluated samples. Out of those isolates, $10(33.3 \%)$ presented the capacity of absorbing ongo red. As for in vivo pathogenicity a $68.0 \%$ of mortality rate of the evaluated samples was observed. Out of 20 isolates tested for cytotoxin production, none of them presented cytotoxic effect in the Vero cells. The Salmonella spp was isolated only in one sample $(0.04 \%)$, and it was identified as Salmonella enterica subspecies houtenae. Results obtained through this research indicate the need for new studies to identify other virulence factors of $E$. coli samples and to delineate the phylogenetic profile of the isolates in order to establish a relation with colibacillosis outbreaks in chickens and broilers in the studied region, as well as to analyze the critical points in the aviculture productive chain to identify the source of Salmonella enterica subspecies houtenae.
\end{abstract}

INDEX TERMS: Enterobacteriaceae, Salmonella spp., Escherichia coli, Passer domesticus.

\footnotetext{
${ }^{1}$ Received on April 18, 2012.

Accepted for publication on May 16, 2012.

${ }^{2}$ Médico(a) Veterinário(a), autônomo(a), Rua Caratinga 62, sala 1, Madalena, Recife, PE 50720-490, Brazil.

${ }^{3}$ Unidade Acadêmica de Garanhuns, Universidade Federal Rural de Pernambuco, Av. Bom Pastor s/n, Boa Vista, Garanhuns, PE 55296-901, Brazil. Tel/fax: (87) 3761-0969.

${ }^{4}$ Departamento de Microbiologia e Imunologia, Instituto de Biologia, Universidade de Campinas, Cidade Universitária Zeferino Vaz, Rua Monteiro Lobato 255, Campinas, SP 13081-862, Brazil. Tel: (19) 3788-6268.

${ }^{5}$ Departamento de Medicina Veterinária, Universidade Federal Rural de Pernambuco, Rua Dom Manuel de Medeiros s/n, Dois Irmãos, Recife, PE 52171-900, Brazil. * Corresponding author: rinaldo.mota@hotmail.com

${ }^{6}$ Laboratório de Enterobactérias, Departamento de Bacteriologia, Pavilhão Rocha Lima, Instituto Oswaldo Cruz, Fiocruz, Av. Brasil 4365, Rio de Janeiro, RJ 21045-900, Brazil. Tel.: (21) 2598-4277.
}

RESUMO.- [Pesquisa de Salmonella spp. e avaliação da patogenicidade, citotoxidade de isolados de Escherichia coli procedentes de pardais (Passer domesticus).] Objetivou-se com este estudo pesquisar a ocorrência de Salmonella spp. e Escherichia coli em amostras de fezes de pardais, além de avaliar a patogenicidade, citotoxicidade e perfil de sensibilidade dos isolados frente a antimicrobianos. Foram capturados 228 pardais em oito granjas. 0 teste de patogenicidade in vitro foi realizado por meio do cultivo dos isolados em ágar oxalato de magnésio acrescido de vermelho de congo, enquanto o teste de patogenicidade in vivo foi realizado em pintos de um dia. Para o estudo dos indicadores dos efeitos citotóxicos, as amostras foram inoculadas em células Vero. Os resultados obtidos quanto 
ao isolamento de Escherichia coli confirmaram a presença deste microorganismo em $30(13,2 \%)$ amostras analisadas. Destes isolados, dez $(33,3 \%)$ apresentaram capacidade de absorção do vermelho congo. Quanto à patogenicidade in vivo observou-se uma taxa de mortalidade de $68,0 \%$ das amostras analisadas. Dos 20 isolados testados quanto à produção de citotoxina, nenhum apresentou efeito citotóxico nas células Vero. Obteve-se o isolamento de Salmonella spp. em apenas uma amostra $(0,04 \%)$, sendo tipificada em Salmonella enterica subespécie houtenae. Os resultados obtidos nesta pesquisa indicam a necessidade da realização de novos estudos para identificar outros fatores de virulência das amostras de E. coli e traçar o perfil filogenético dos isolados para estabelecer uma relação com surtos de colibacilose em galinhas e frango de corte na região estudada, além de analisar os pontos críticos na cadeia produtiva da avicultura para identificar a origem da Salmonella enterica subespécie houtenae.

TERMOS DE INDEXAÇÃO: Enterobacteriaceae, Salmonella spp., Escherichia coli, Passer domesticus.

\section{INTRODUCTION}

In the modern poultry industry the utilization of a biosecurity program is vital, aiming the maintenance of breeding stocks free from microorganisms which cause impacts on poultry production, or at least, keeping them under control. Amongst the main pathogens responsible for direct or indirect losses for the poultry productivity, one can point out the Escherichia coli and Salmonella spp., with the latest prone to vertical transmission and of relevance for Public Health (Andreatti Filho 2007).

Several pathogenic agents may be carried by bearer/ reservoirs birds, disseminated by secretions and/or by excrements and, yet, transmitted by ectoparasites which parasite those birds (Hubálek 2004). In literature, it is observed papers that mention the participation of wild birds in the microorganisms' dissemination (Rappole \& Hubalek 2000).

In the industrial poultry breeding, avian colibacillosis is one of the major problems, characterized by any systemic or local infection caused by pathogenic E. coli (Saindnberg \& Knöbel 2005). In this animal species, E. coli samples that present few virulence factors are named APEC. Those are associated to extra-intestinal infections, mainly in the respiratory tract or systemic infection that result in a diversity of diseases that cause severe economic losses (Dho-Moulin \& Fairbrother 1999).

Salmonellosis is another important illness in poultry breeding, caused by bacteria from Salmonella species, which seems to be more prevalent in areas of intensive animal production, especially some poultry types raised in confinement (OIE 2004). Domestic and wild animals may be bearers of bacteria from Salmonella genus, disseminating them in their environment. These bacteria may cause acute and/or chronic diseases to the susceptible animals. Therefore, its control is difficult due to its epidemiologic complexity, involving the vertical transmission, fecal excretion, horizontal transmission, environmental contamination and the existence of reservoirs of these agents in different species (Soncine \& Back 2001).

In poultry farms at the Agreste of the State of Pernambuco (Brazil), sparrows are frequently observed in hens or broilers aviaries, as well as in feed storage facilities, consisting in a probable risk factor for infectious agents' transmission. Taking into account the cohabitation of this species with commercial poultry, this study aimed to investigate the occurrence of Salmonella spp and Escherichia coli in samples proceeding from sparrows, as well as to evaluate the pathogenicity, cytotoxicity and sensitivity profile of E. coli isolates.

\section{MATERIALS AND METHODS}

\section{Samples}

For the sample collection, 228 sparrows were captured in eight farms, distributed into broilers' (four), breeders' (three) and commercial hens' (one), situated in six districts of the Agreste of the State of Pernambuco. For this study, sex and age of animals were not considered. Samples were collected by using manufactured and sterilized swabs, adapted for introduction into each animal's cloaca. Fecal samples were sent to the laboratory in isothermal boxes containing recyclable ice for the proper processing.

Isolation, identification, Escherichia coli pathogenicity and cytotoxicity tests

For the E. coli isolation, samples were inoculated in peptonated water (Oxoid, England) and incubated in microbiological incubator at $37^{\circ} \mathrm{C}$ for 24 hours. Next, an aliquot was seeded in Eosin Methylen Blue agar (EMB) (Oxoid, England) for 24 hours at $37^{\circ} \mathrm{C}$. For the isolates confirmation, biochemical proofs were performed (Citrate, Voges-Proskauer, Methyl Red, Lysine, Urea, Triple Sugar Iron [TSI], Indole, Motility and production of sulfidric gas [SIM]) (Carter 1988).

The in vitro pathogenicity test was performed by cultivation of isolates in congo red-magnesium oxalate agar (Berkhoff \& Vinal 1986). The in vivo pathogenicity test was performed with an inoculum prepared from the culture of $E$. coli samples in brain-heart broth (BHI) (Oxoid, England). Inoculation was performed through air sac, using for each isolate seven one day-old chicks, from which five were inoculated with $0.1 \mathrm{ml}$ of bacterial suspension at the approximate concentration of $10^{7}$ colony-forming units (CFU/ $\mathrm{mL}$ ) and two control, inoculated with $0.1 \mathrm{ml}$ of BHI broth (Assis \& Santos 2001). Inoculated animals were observed every 12 hours for mortality up to 72 hours after inoculation. Birds that died during this period were necropsied for observation of macroscopic lesions, peculiar to the disease (Berkhoff \& Vinal 1986).

For the study of cytotoxic effects indicators, samples were inoculated into Vero cells, obtained from the Adolpho Lutz Institute. Cells were cultivated in 96 wells-microplates in Eagle media (MEM) with the addition of fetal bovine serum (FBS) at $10 \%$. After 24 hours, the plate was withdrawn from the incubator and the media, discarded. A volume of $50 \mu$ l of Eagle media (MEM) with the addition of $10 \%$ of bovine fetal serum were added and right next, $50 \mu \mathrm{l}$ of the sterile supernatant corresponding to each bacterial sample were inoculated, pure and in dilutions of $10^{-1}, 10^{-2}$ and $10^{-3}$. Microplate was incubated at $37^{\circ} \mathrm{C}$, in incubator at $5 \%$ of $\mathrm{CO}_{2}$. The first readings were performed each 1 hour, and after 6 hours they were spaced to every 12 hours, until 72 hours of test were completed. Readings were performed in inverted optical microscope. 


\section{Isolation and identification of Salmonella spp.}

For the isolation of Salmonella spp, samples were pre-enriched in buffered peptonated water at $1 \%$ and incubated at $37^{\circ} \mathrm{C}$ for 24 hours. After this period, $1 \mathrm{ml}$ was transferred to $10 \mathrm{ml}$ of Selenite-Cystine broth (Oxoid, England) and Rappaport Vassiliadis broth (Oxoid, England) with Novobiocine at 4\% (SIGMA, USA), which were incubated at $37^{\circ} \mathrm{C}$ for 24 hours. From the enrichment broths, samples were seeded in plates containing Xylose Lysine Deoxicolate agar (XLD) (Oxoid, England) and Brilliant Green agar (Oxoid, England) media, which were incubated at $37^{\circ} \mathrm{C}$ for 24 hours. Suspicious colonies were submitted to the Triple Sugar Iron agar (TSI) (Oxoid, England), Lysine-Iron agar (LIA) (Oxoid, England) and urea broth (Oxoid, England) biochemical proofs (Costa \& Hofer 1972) and incubated at $37^{\circ} \mathrm{C} / 24 \mathrm{~h}$. After the presumably identification, suspicious samples were sent to the Enterobacteria Laboratory, of the Oswaldo Cruz Institute Foundation (Fiocruz), RJ in nutrient agar (Oxoid, England) for confirmation of genus and serotype typification (Le minor \& Popoff 1987).

Sensitivity profile to antimicrobials of Escherichia coli isolates

$E$. coli samples were submitted to the sensitivity test (NCCLS 2004). Antimicrobials used were amoxicillin (10mcg), norfloxacin (5mcg), phosphomycin (20mcg), cyprofloxacin (5mcg), sulfazotrin (25mcg) and doxicyclin (30mcg) (CECON, Brazil). Results interpretation was performed according to manufacturer specification.

\section{Statistical analysis}

The results obtained were analyzed by using absolute and relative frequency dispersion. For the concordance study amongst the tests the Kappa coefficient $(\mathrm{K})$ and the conventional interpretation of the $\mathrm{K}$ values were: $0.00-0.20=$ weak concordance; 0.21 $0.40=$ regular; $0.41-0.60=$ moderate; $0.61-0.80=$ god; $0.81-1.0=$ very good, negative values are interpreted as equivalent to 0.00 (Landis \& Koch 1977).

\section{RESULTS}

Results obtained for the E. coli isolation confirmed the presence of this microorganism in $30(13.2 \%)$ analyzed samples. Out of these isolates, ten $(33.3 \%)$ presented the capacity of absorbing congo red. As for in vivo pathogenicity, a $68.0 \%$ mortality rate of the analyzed samples was observed. The concordance among the in vivo and in vitro pathogenicity tests demonstrated a poor concordance $(\mathrm{K}<0.00)$.

At the chicks necropsy, accentuated hemorrhages in the air sacs, kidneys, liver and lungs were observed.In the 20 isolates tested for the cytotoxin production, none of them presented cytotoxic effect in Vero cells.

Table 1. Sensitivity profile of Escherichia coli isolates obtained from cloacal swabs of sparrows (Passer domesticus Linnaeus, 1758) captured in poultry farms in the State of Pernambuco

\begin{tabular}{|c|c|c|c|c|}
\hline \multirow[t]{3}{*}{ Antibiotics } & \multicolumn{4}{|c|}{ Interpretation } \\
\hline & \multicolumn{2}{|c|}{ Sensitive } & \multicolumn{2}{|c|}{ Resistant } \\
\hline & A.F. & R.F. $^{\mathrm{b}}(\%)$ & A.F. ${ }^{a}$ & R.F. $^{b}(\%)$ \\
\hline Sulfazotrin (25mcg) & 21 & 75.0 & 7 & 25.0 \\
\hline Phosphomycin (20mcg) & 27 & 96.4 & 1 & 3.6 \\
\hline Cyprofloxacin (5mcg) & 23 & 82.1 & 5 & 17.9 \\
\hline Norfloxacin (5mcg) & 13 & 46.4 & 15 & 53.6 \\
\hline Doxicyclin $(30 \mathrm{mcg})$ & 16 & 57.1 & 12 & 42.9 \\
\hline Amoxicillin (10mcg), & 21 & 75.0 & 7 & 25.0 \\
\hline
\end{tabular}

a Absolute Frequency, ${ }^{\mathrm{b}}$ Relative Frequency.
Results obtained in 28 sensitivity tests to antimicrobial of $E$. coli samples are presented in Table 1.

When the multi-resistance profile was analyzed, it was observed that five $(17.8 \%)$ samples were resistant to three antibiotics or more.

As for the Salmonella spp. isolation, it was obtained frequency of $0.04 \%(1 / 228)$. In the sample typification, the observed species was the Salmonella enterica subspecies houtenae.

\section{DISCUSSION}

This was the first study performed in the country's North-Northeast for isolation of bacteria from the Enterobacteriaceae family in domestic sparrows. In wild animals, a few studies were performed in order to isolate Escherichia coli. Cultivated feces of 125 psittacines apparently healthy to determine the E. coli occurrence and found results below to $13.6 \%$ of positive samples (Graham \& Graham 1978). Significant differences were shown in the colonization by E. coli in psittacines, with $20.0 \%$ of positive birds at the recreational zoo in the district of Jundiá, São Paulo, Brazil (Mattes et al. 2005). Morishita et al. (1999) reported a frequency of $17.2 \%$ of $E$. coli isolation proceeding from 373 swabs of sparrows' cloacae. Although these authors considered the frequency of $17.2 \%$ of this bacteria isolation in sparrows as low, they concluded that this species may represent an important dissemination source of pathogenic agents into the environment. They even argued that the urban habits of those birds which are usually found feeding from grains in feed storage facilities and garbage dumps may predispose the infection by E. coli and Salmonella spp. In the poultry farms at the Agreste region of the State of Pernambuco, Brazil, great circulation of those birds was observed inside broiler, breeders and hens houses, as well as their presence inside ration factories in some of those poultry farms.

The correlation among the pathogenic capacity of E. coli samples and its capacity of absorption of congo red was not perfect in this study, since samples that did not absorb the congo red presented an elevated mortality rate in the pathogenicity test in vivo. This deficient correlation among those tests was also previously observed (Corbett, Berkhofe \& Vinal 1987). These authors concluded that there was no correlation among the pathogenicity of $E$. coli samples of one day-old chicks with the colonies dying in the media with Congo red and with or without swine bile. They also concluded that this method is not efficient as a diagnosis technique.

Based on the in vivo pathogenicity tests results where the presence of some pathogenic samples was confirmed, an important epidemiologic relation among the sparrows isolates with the isolates of broilers and chickens with clinic feature of colibacillosis could be established. However, in order to confirm this relation, molecular studies analyzing the phylogenic profiles of isolates of both species are necessary.

The macroscopic findings observed in one day-old chicks confirm the colisepticaemic feature, according to the lesions described (Cheville \& Arp 1978). Colisepticaemia outbreaks in laying hens caused by invasive and pathogenic 
strips of $E$. coli characterized by the clinical and anatomopathological findings and laboratorial tests in five commercial laying farms in the State of Pernambuco, Brazil (Vilela et al. 2006). In the anatomopathological findings, accentuated lesions in the oviduct, ovaries, air sacs and kidneys were observed. In wild birds, the main observations for the colisepticaemia are prostration, anorexia, diarrhea and polyuria, renal involvement, serofibrinous arthritis, which severity is dependent upon the infection chronicity. Microscopically, a serofibrinous inflammation with infiltrate of inflammatory cells is observed in liver and kidneys (Gerlach 1994).

Concerning the cytotoxin production, none of the samples caused cytotoxic effect on the Vero cells. Although these samples do not produce cytotoxin, they produced high chick mortality rate in the in vivo pathogenicity test (68.0\%). Evaluated the cytotoxic effect on the mortality rate of one day-old chicks inoculated with samples of producing and non-producing verotoxins $E$. coli, and observed that the cytotoxic effect also did not influence the mortality rate of inoculated chicks (Assis e Santos 2001). These findings reinforce those of the mentioned authors, since in this study the capacity of lesions production was not associated to this toxin production.

In the in vitro sensitivity profile, an elevated resistance rate to the use of the antibiotics Norfloxacin and Doxicyclin of the analyzed strains was observed. In association, a multiresistance profile of $17.8 \%$ was observed. These results confirm the habitual observation in aviculture, which is the indiscriminate use of antibiotic in ration and water provided to the birds, in order to prevent or treat diseases. As observed in this study, sparrows have free access to the facilities where birds are housed and to ration factories, and therefore, they also have access to rations with antimicrobials, which would explain the resistance of these birds isolates. Isolates of $E$. coli proceeding from wild birds were also submitted to in vitro antimicrobial evaluation and it was verified that all of them were resistant to lincomycin, frequently associated to streptomycin $63.0 \%$ (Ikuno et al. 2004).

Antimicrobials administration to animal and humans causes a selective pressure and increases the potential risk for selection of resistant bacteria to antimicrobials (Schwarz \& Chaslus-Dancla 2001). Literature reports that the resistance level may remain constant, or may increase, independently of antimicrobials (Khachatryan et al. 2004). As for commensal $E$. coli of animals, it is observed that this microorganism is resistant to most of the antimicrobials agents commonly used, as tetracycline, sulfamethoxazole, ampicillin and streptomycin (Kang et al. 2005).

E. coli characterization for the resistance pattern to antibiotics and the identification of the virulence pattern are important epidemiologic information for characterizing clinical isolates, as of birds, as of water and environment, and allow discriminating the pathogenic potential of these bacteria and the identification of emergent pathogenic clones (Ikuno et al. 2004).

As for Salmonella spp., a low isolation frequency was obtained. For the typification, it was identified the Salmo- nella enterica subspecies houtenae, and this was the first report of this serotype in wild birds in Brazil. Nowadays, this serotype does not have economic relevance for poultry production, since there are no reports of isolations, or mentions to possible losses on productivity cause by Salmonella enterica subspecies houtenae. However, this finding is important for the epidemiologic chain and will provide subsidies for breakouts prevention caused by Salmonella, since once the typification of this agent in the aviculture's productive chain is confirmed, it is possible to relate the isolation to the presence of sparrows in farms, and once those can act as source of infection.

In sparrows (Passer domesticus), few studies were performed around the world in order to identify Salmonella as a likely source of infection or to determine the infection prevalence in this species. Investigation on Salmonella in several cities of the Czech Republic, between 1984 and 1991, in sparrows and they determined an incidence of $22.6 \%$ (Cízek et al. 1994). The infecting dose and the incubation period of an isolate of Salmonella enteric serotype Typhimurium serotype 160 (DT160) proceeding from naturally infected sparrow was analyzed in 2006 and concluded that was a pathogenic strain and the incubation period lasted at least 10 days (Conolly et al. 2006). Moreover, those sparrows may serve as infection source to the man and other contacting animals. Investigated the mortality caused by Salmonella in this species and determined a rate of $35.1 \%$ (Hall \& Saito 2008). Nevertheless, knowing the Salmonella serotypes prevalence in certain source of infection or geographic region provides economy of time and material used for diagnosis of antigenic structures of local laboratories (Hofer et al. 1997).

Results obtained through this research indicate the necessity to perform new studies to identify other virulence factors of $E$. coli samples and to delineate the isolates phylogenetic profile in order to establish a relation amongst colibacillosis outbreaks in chickens and broilers in the studied region, as well as to analyze the critical points in the aviculture's productive chain to identify the origin of Salmonella enterica subspecies houtenae.

Acknowledgement.- To CNPq (National Council for Scientific and Technological Development of the Brazilian Government).

\section{REFERENCES}

Andreatti Filho R.L. 2007. Colibacilose aviária, p.112-117. In: Andreatti Filho R.L. (Ed.), Saúde Aviária e Doença. Roca, São Paulo. 314p.

Assis A.C.B. \& Santos B.M. 2001. Patogenicidade in vivo e in vitro de amostras de 331 Escherichia coli de origem aviária. Revta Bras. Ciênc. Avícola 3:181-184.

Berkhoff H.A. \& Vinal A.C. 1986. Congo red medium to distinguish between invasive and non invasive Escherichia coli pathogenic for poultry. Avian Dis. 30:117-121.

Carter G.R. 1988. Fundamentos de Bacteriologia e Micologia Veterinária. Roca, São Paulo. 249p.

Cheville N. \& Arp L.H. 1978. Comparative pathologic finding of Escherichia coli infection in birds. J. Am. Vet. Med. Assoc. 173:584-587.

Cízek A., Litérak I., Hejlicék K., Treml F. \& Smola J. 1994. Salmonella contamination of the environment and its incidence in wild birds. Zentralbl. Veterinärmed. B 42:320-345. 
NCCLS 2004. Reference Method for Antimicrobial Susceptibility Testing for Anaerobic Bacteria. National Committee for Clinical Laboratory Standards, West Valley Road, Suite 1400, Wayne, Pennsylvania.

Conolly J.H., Alley M.R., Dutton G.J. \& Rogers L.E. 2006. Infectivity and persistence of an outbreak strain of Salmonella enterica serotype Typhimurium DT160 for house sparrows (Passer domesticus) in New Zealand. N. Z. Vet. J. 54:329-332.

Corbett W.T., Berkhofe H.Q. \& Vinal A.C. 1987. Epidemiologic study to evaluate Congo red binding in Escherichia coli. Can. J. Vet. Res. 51:312-315.

Costa G.A. \& Hofer E. 1972. Isolamento e identificação de Enterobactérias. Monografia, Instituto Osvaldo Cruz, Rio de Janeiro. 120p.

Dho-Moulin M. \& Fairbrother J.M. 1999. Avian pathogenic Escherichia coli. Vet Res. 30:299-316.

Gerlach H. 1994. Bacteria, p.949-983. In: Ritchie B.W., Harrison G.J. \& Harrison L.B. (Eds), Avian Medicine: Principles and application. Wingers Publishing Inc., Florida. 1384p.

Graham C.L. \& Graham D.L. 1978. Occurrence of Escherichia coli in feces of psittacine birds. Avian Dis. 22:717-720.

Hall A.J. \& Saito E.K. 2008. Avian wildlife mortality events due to salmonellosis in the United States, 1985-2004. J. Wildl. Dis. 44:585-593.

Hofer E., Silva Filho S.J. \& Reis E.M.F. 1997. Prevalência de sorovares de Salmonella isolados de aves no Brasil. Pesq. Vet. Bras. 17:55-62.

Hubálek Z. 2004. An annotated checklist of pathogenic microorganism associated with migratory birds. J. Wildl. Dis. 40:639-659.

Ikuno A.A., Gustalli E.A.L., Guimarães M.B. \& Ferreira V.C.A. 2004. Características de isolados de Escherichia coli provenientes de aves silvestres quanto a genes de virulência e resistência a antibióticos. XXXVII Congresso Brasileiro de Medicina Veterinária, Gramado, RS. (Resumo)

Kang H.Y., Jeong Y.S., Oh J.Y., Tae S.H., Choi C.H., Moon D.C., Lee W.C., Seol S.Y., Cho D.T. \& Lee J.C. 2005. Characterization of antimicrobial resis- tance and class 1 integrons found in Escherichia coli isolates from humans and animals in Korean. J. Antimicrob. Chemoter. 55:639-644

Khachatryan A.R., Hancock D.D., Besser T.E. \& Call D.R. 2004. Role of calf-adapted Escherichia coli in maintenance of antimicrobial drug resistance in dairy calves. Appl. Environ. Microbiol. 71:752-757.

Landis J.R. \& Koch G.G. 1977. The measurement of observer agreement for categorical data. Biometrics 33:159-174.

Le Minor L. \& Popoff M.Y. 1987. Designation of Salmonella enterica sp. Nov. as the type and only species of the genus Salmonella. Int. J. Syst. Evol. Microbiol. 37:465-468.

Mattes B.R., Consiglio S.A.S., Almeida B.Z., Guido M.C., Orsi R.B., Silva R.M., Costa A., Ferreira A.J.P. \& Knöbl T. 2005. Influência da biossegurança na colonização intestinal por Escherichia coli em psitacídeos. Arqs Inst. Biológico, São Paulo, 72:13-16.

Morishita T.Y., Aye P.P., Ley E.C. \& Harr B.S. 1999. Survey of pathogens and blood parasites in free-living passerines. Avian Dis. 43:549-552.

OIE 2004. Salmonellosis. Manual of diagnostic test and vaccines for terrestrial animals. $5^{\text {th }}$ ed. World Organization for Animal Health, Geneva.

Rappole J.H. \& Hubalek Z. 2000. Migratory birds and West Nile virus. J. Appl. Microbiol. 94:47-58.

Saidenberg A.B.S. \& Knöbl T. 2005. Colibacilose em aves silvestres. Ciênc. Vet. Tróp. 8:16-28.

Schwarz S. \& Chaslus-Dancla E. 2001. Use of antimicrobials in veterinary medicine and mechanisms of resistance. Vet. Res. 32:201-225.

Soncine R.A. \& Back A. 2001. Salmonella enteritidis em aves: erradicação ou controle por vacinação. Conferência APINCO de Ciência e Tecnologia Avícolas, Campinas, SP, p.21-30. (Resumo)

Vilela S.O., Pinheiro Junior J.W., Barbosa R.A., Medeiros E.R. \& Mota R.A. 2006. Surto de colisepticemia em poedeiras comerciais provenientes de granjas no estado de Pernambuco. Ciênc. Vet. Tróp. 9:36-40. 